\title{
Customer Retention: Key towards Sustaining Competitiveness in Commercial Banking in South Africa
}

\author{
R. Haripersad \\ Absa Bank Limited \\ South Africa \\ Dr Barnes Sookdeo \\ Senior Lecturer \\ Department of Operations Management \\ College of Economic and Management Sciences \\ University of South Africa \\ South Africa
}

\begin{abstract}
Customer retention is an important component of banking strategy in today's increasingly competitive environment. Worldwide, banks are struggling to sustain their competitiveness, which hinders their traditional income streams. The foremost challenges banks are currently facing are cost containment and customer retention. Therefore, a relentless focus on customer retention is required to sustain their competitiveness. This article sought to explore factors, which bank customers consider in their decision to leave their current bank for a competitor. Semi-structured interviews were conducted to identify the factors, which prompt customers to switch banks. A thematic analysis of data identified four themes concerning retention. The empirical findings suggest that customers sought an experience that made them feel special and valued. The results also show that essentially, banks that pay special attention to their customers will succeed in retaining their customers.
\end{abstract}

Keywords: commercial banking, customer retention; customer relationship management, competitiveness.

\section{Introduction}

What would frustrate customers enough to switch banks?"One would be surprised to learn that it is not benefits, or rewards, or a cheaper alternative that would make them move, but impolite, rude or uninterested staff. This is a wake-up call for local banks, but South Africans are not alone in their number one reason why they would switch banks" (Fin24, 2015).A recent customer loyalty study found that although consumers globally trusted banks more than other service providers, only $24 \%$ of the 18,000 consumers surveyed in nine countries indicated that their bank delivered good service (Verint, 2015).

Customer retention is an important component of banking strategy in today's increasingly competitive environment (Cohen, Gan, Ay Yong \&Chong, 2007). Commercial banks around the world are struggling to sustain their competitiveness, which is hindering their traditional income streams. The two foremost challenges that banks face are cost containment and customer retention. Aguinis, Gottfredson and Joo (2012) states that organisational performance can be improved through a range of reasons. There are varieties of management tools available to improve organisational performance. One such tool is customer relationship management (CRM).

CRM refers to building one-to-one relationships with customers that can drive value for the firm. Traditionally, people have thought and dealt with CRM from a marketing perspective. For the purposes of this article, CRM is dealt with from a management perspective. The largest South African (SA) industry contributors to the gross domestic product (GDP) in the third quarter of 2013 were the finance, real estate and business services, contributing 21,4\% as reported by Statistics South Africa, (2013a). According to The Banking Association of South Africa (2012), the financial services sector contributed about 10,5\% to the GDP, and has continued to grow by $2,9 \%$ annually. They add that the 2012 South African banking sector overview shows that the financial services industry was the third largest employer in the country, employing over 150000 people, representing about $13,1 \%$ of total employment. The SA banking industry is made up of 17 registered banks, two mutual banks, 12 local branches of foreign banks, and 41 foreign banks. 
The four major banks (ABSA, FirstRand, Nedbank and Standard Bank) represented about $84 \%$ of the market share. According to the 2011 banking survey by PricewaterhouseCoopers (PwC)(2011), the four major banks held 34,5 million retail accounts in 2009, essentially making banking a very important sector of the SA economy.

On the revenue side, longer-term customers have been found to buy greater volumes at greater margins thereby increasing cost to income ratio (Reichheld, 2009:39). On the cost side, it costs six to eight times more to acquire new customers than it does to retain existing customers. Service quality, customer satisfaction, trust, switching costs, pricing, and brand image are some of the factors which influence whether a customer will remain with a bank or not (Bloemer \& Kasper, 2008:166; Baumann, Burton \& Elliott, 2008:105; Colgate \& Lang, 2011:16).Baumann, Burton and Elliott (2008:75) stress that commercial banks have to make sure that they manage their relationships with their customers and retain their existing customers, as it is more economical to retain existing customers than to attract new customers. This article reports on the investigation that was conducted to determine the factors that influence customers to leave their bank for a competitor. The motivation for the investigation emanated from the review of related literature, which highlighted the impact of the 2008 global financial economic crisis. It is envisaged that this article assists to broaden the understanding of CRM and its role in enhancing customer value in the face of fading customer confidence. This is preceded by a discussion of the findings. The article concludes with the recommendations and suggestions for future research.

\subsection{Purpose and objectives}

The purpose of the study was to explore the factors which banking customers consider in their decision to leave their current bank for a competitor. Better understanding of the reasons why customers decide to leave their bank should provide decision makers with more specific information needed to retain customers. The primary objective of this study was to explore factors, which customers consider in their decision to leave their current bank for a competitor. The secondary objectives of the study were to describe and make recommendations to on customer retention strategies.

\subsection{Problem investigated}

"The argument for customer retention is relatively straightforward. It is more economical to keep customers than to acquire new ones" (Cohen, et al. 2007). "Retail banks around the world are struggling to sustain their competitiveness in the face of severe external challenges. Massive debt loads are threatening the global economy, while stringent regulations put in place as a result of the financial crisis of 2008 are hindering traditional income streams" (Lassignardie \& Desmarès, 2012:3). The PWC(2013) SA Banking Survey reported that local bank CEOs agreed that their third most pressing issue is customer retention, and a relentless focus on customer retention is required. Essentially banks' operating costs are high and their income stream is hindered as they struggle to retain customers, which threatens their competitiveness. Hence, the formulated problem statement of this article is that banks do not have an enhanced understanding of customer retention strategies to prevent customers switching banks for the competitor.

\section{Literature Review}

The literature review focused on customer retention, competition, improving the service experience, enriching the experience, and customer satisfaction in commercial banking.

\subsection{Customer retention}

According to Matanga (2008), "customer retention is a measure of customer loyalty based on an organisation's success in retaining the business of its existing customers". Hoffman and Bateson (2006) state that customer retention is one of the benefits of relationship marketing, and customer retention refers to concentrating the organisation's marketing efforts toward the existing customer base. Customer retention focuses only on developing marketing strategies that cause repeat-purchasing behaviour. Hoffman and Bateson (2006) further state that in contrast to seeking new customers, organisations engage in efforts directed towards customer retention in order to satisfy existing customers. The needs of the customers are increasing and the competitiveness among the different institutions within this sector has been similarly increasing. Winning in the highly competitive commercial banking market means convincing customers to come through the door and also convincing them to stay. Improved efficiency and simplification of the on-boarding process makes it easier for a customer to join a bank (PwC, 2013). Developing long-term relationships with customers should be the ultimate goal of organisations, if they want to grow their business. 
Griffin and Lowenstein (2001) state that the longer a company retains a customer; the more profit the customer generates. Bank management must identify and improve upon factors that can limit customer defection. These include employee performance and professionalism, willingness to solve problems, friendliness, and level of knowledge, communication skills, and selling skills, amongst others. The banking industry is highly competitive, with banks not only competing amongst each other; but also with non-banks and other financial institutions (Boulding, Kalra, Staelin \& Zeithaml, 2009:18).

In order to gain the advantage in the highly competitive commercial banking market means that banks must understand the value of customer retention. The literature is clear on the point - the longer a company retains a customer; the more profit the company generates. Therefore, a positive relationship between the bank and the customer is significant since this is capable of influencing retention as the customer will experience feelings of trust and satisfaction towards the bank.

\subsection{Competition in commercial banking}

Rootman, Tait and Sharp (2011) observe that competition in the banking sector worldwide has been increasing, which has made it very difficult for commercial banks to provide their customers with exclusive banking services and products as required. In order to deal with this challenge effectively, they have also found that banks that can excel in customer service are capable of benefiting from the advanced CRM, since the customer pays attention to the aspects of interactions and services related to other service providers while examining the services of their own service provider.

Banks reap the rewards of excellent customer service in the form of increased loyalty of customers. This is also becoming the major driver for advancements, as awareness increases the growth, customer retention and possibly also the sustainability of the banks. Rootman, et al., (2011:184), state that some of the advantages for banks include word-of-mouth suggestion, decreased costs for acquiring new customers, increased profitability and higher sales. These advantages can all result in the survival of the banks and create the outcomes of successful techniques for banking.

\subsection{Improving the service experience of the customer}

The need for improving a customer's service experience should be inculcated in the hearts and minds of every employee. It is common knowledge that a happy, satisfied customer is likely to return and or tell others about the good experiences that they had when dealing with your company. Johnston and Kong (2011) state that providing a good experience is also important because it affects customer satisfaction, delivers customer loyalty, influences expectations, instils confidence, and creates emotional bonds with customers or, conversely, leads to emotional scarring. When it comes to a customer having to purchase a service, the customer would possibly select from the specific company that holds a positive sustainable record of customer experience (Howcroft, 2007:15). Hence, there is an urgent need to improve the service experience of the customer.

\subsection{Enriching the customer's banking experience}

Libai, Narayandas and Humby (2009) state that developing improved customer experience is a strategic and complex endeavour. A mixture of human intervention and technology is required to ensure that the experience of the customer is memorable. An additional area where Libai, et al., (2009) found that technology might develop the quality of customer experience is telephonic banking, which is presently riddled with authentication procedures and tedious interactive voice response (IVR) menus. If banks could initiate verification of voice technology towards automatically confirming the identity of the caller, this would result in making phone banking easier.

According to Hennig-Thurau (2004: 466), the search for improved customer banking experience revolves around improving personalisation, efficiency, speed of the service and products and discovering different ways for retaining the customers. It is important to enrich the experiences of the customer, and this includes understanding their expectations and needs and determining the initiatives necessary to meet these expectations. A happy, satisfied customer is likely to return and or tell others about the good experiences that they had when dealing with the bank.

\subsection{Attaining customer satisfaction}

Maurer (2011) states that customer satisfaction quantifies the degree to which banking services and products meet customer expectations. 
Yoshida and James (2010:339) concur by stating that customer satisfaction as "a customer's pleasurable, fulfilment response to services provided during interaction and dealing with a business". They argue that customer satisfaction is not only a criterion to evaluate service quality, but is also a predictor of repeat patronage. Brink and Berndt (2008) argue that customer value is not simply a matter of high quality, instead, customers' value goods and services of the quality they expect, which are sold at the prices that they are willing to pay. If a customer's needs are met during the purchasing process, there is a likelihood that the customer will make repeat purchases and thereafter inform others via word-of-mouth, (Du Plessis, 2010).

Soranno (2009:55), states that a bank should eliminate roadblocks, communicate, improve the culture of the organisation, create a distinctive position and innovate in order to attain customer satisfaction. Banks can satisfy their customers, but they must have a good system in place for listening to their customers. Only when banks know its customers' opinions, can they determine which aspects of the service they are dissatisfied with, and thus work to improve them (Alvarez, Martin \&Casielles, 2011:156).

\section{Research Methodology}

The purpose of this study was to explore the factors that banking customers consider in their decision to leave their current bank for the competitor. This implies an understanding which locates the study in the interpretivistic research paradigm, denoting a qualitative study (Denzin \& Lincoln, 2013; Henning, Marshall \& Rossman, 2011). An exploratory study was warranted. The research design was qualitative in nature and aimed to provide an indepth description of a small number of cases (Mouton, 2001:149).

The population comprised individuals leaving banks for the competition. Details of such individuals were obtained from a business banker directory of the bank where the researcher was employed. Non-probabilistic, purposive sampling was used for this study. In determining the sample size for this study, the researcher applied the learning from the study by Guest, Bunce and Johnson, (2006), which asked the question: "How many interviews are enough?" - based on the concept of "saturation," or the point at which no new information or themes are observed in the data. They state that saturation occurred between six and 12 interviews. Hence, it was decided to purposely select twelve bank customers who had left for the competition.

Data collection took the form semi-structured interviews, using audio-tapes and documenting conversations (field notes) with interviewees. The data obtained from the interviews were analyzed and transcribed verbatim using the thematic analysis method (Braun \& Clarke, 2006) to represent the hierarchical relationships between the themes. The theme codebook (Table 1) was created to contain a definition of each major theme and each subtheme within that major theme. The thematic analysis was used to identify patterns and themes from the transcribed interviews as they emerged. From the themes, various sub-themes were developed as the analysis was further refined. Themes and sub-themes were coded using a numerical coding system.

Table 1: Theme codebook

\begin{tabular}{|l|l|l|l|l|l|}
\hline \multicolumn{2}{|l|}{ Level } & Theme & Description & $\begin{array}{l}\text { Theme } \\
\text { statement }\end{array}$ \\
\hline 1 & $\mathbf{2}$ & $\mathbf{3}$ & Service & $\begin{array}{l}\text { A valuable action, deed, or effort performed } \\
\text { to satisfy a need or to fulfil a demand. }\end{array}$ & $\begin{array}{l}\text { The quality of customer } \\
\text { service in the banking } \\
\text { sector. }\end{array}$ \\
\hline 1.0 & & & $\begin{array}{l}\text { Service } \\
\text { quality }\end{array}$ & $\begin{array}{l}\text { Ansessment of how well a delivered } \\
\text { service conforms to th customer's } \\
\text { expectations. }\end{array}$ & $\begin{array}{l}\text { Characteristic of a service that is } \\
\text { committable operable or usable upon } \\
\text { demand to perform its requiredfunction. }\end{array}$ \\
\hline & 1.2 & & $\begin{array}{l}\text { Service } \\
\text { availability }\end{array}$ & $\begin{array}{l}\text { To make or alter to individual or personal } \\
\text { specifications. }\end{array}$ \\
\hline 1.3 & & $\begin{array}{l}\text { Service } \\
\text { customisation/ } \\
\text { Personalised } \\
\text { service }\end{array}$ & $\begin{array}{l}\text { Customer } \\
\text { service }\end{array}$ & $\begin{array}{l}\text { A series of activities designed to enhance the } \\
\text { level of customer satisfaction - that is, the } \\
\text { feeling that a product or service has met the } \\
\text { customer expectation. }\end{array}$ & \\
\hline
\end{tabular}




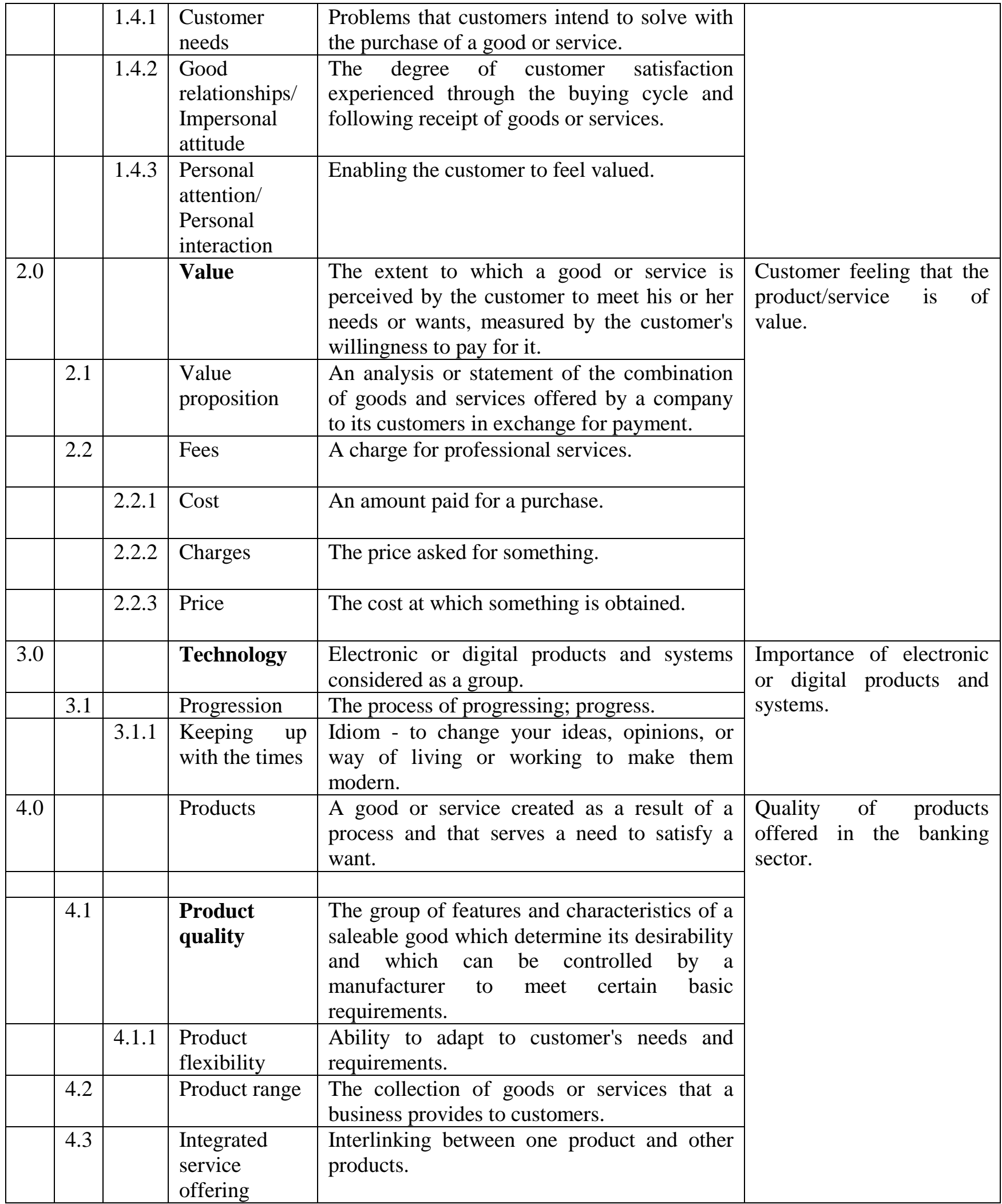

\section{Results and Discussion}

From the transcribed conversations, patterns of experiences were listed. These came from direct quotes or paraphrases of the participants. When patterns emerged during the interviews, participants were asked for feedback on these patterns. When a single response containing more than one theme emerged, the participant was asked to elaborate so that themes could be categorised. 
Related patterns were combined and categorised into sub-themes. Themes that emerged from the participant's stories were integrated to form a comprehensive picture of their collective experiences. Themes were chosen by reading related literature and matching it to the themes that emerged during the interview process. After collating the themes and reviewing the literature, theme statements were developed. The themes and sub-themes were coded and arranged in a logical way throughout the process. These were recorded in the first three columns. The actual utterances of the participants were translated into themes and sub-themes, as they emerged, and were recorded in the fourth column. Most of the meanings of the themes and sub-themes were transcribed from the participants' perspective and compared to the internet's Online Business Dictionary (OBD). Parts of the descriptions were recorded as per the participants' perspective as formal definitions were not available to make a direct comparison. Descriptions were recorded in the fifth column and the theme statements were recorded in the sixth column. The theme statement is a collective of the theme and sub-themes, and utterances of the participants.

\subsection{Profile of the participants}

The first twelve participants that volunteered to participate and qualified by confirming that they had switched banks were interviewed. Once a sample size of twelve was reached, the researcher concluded the data gathering process.

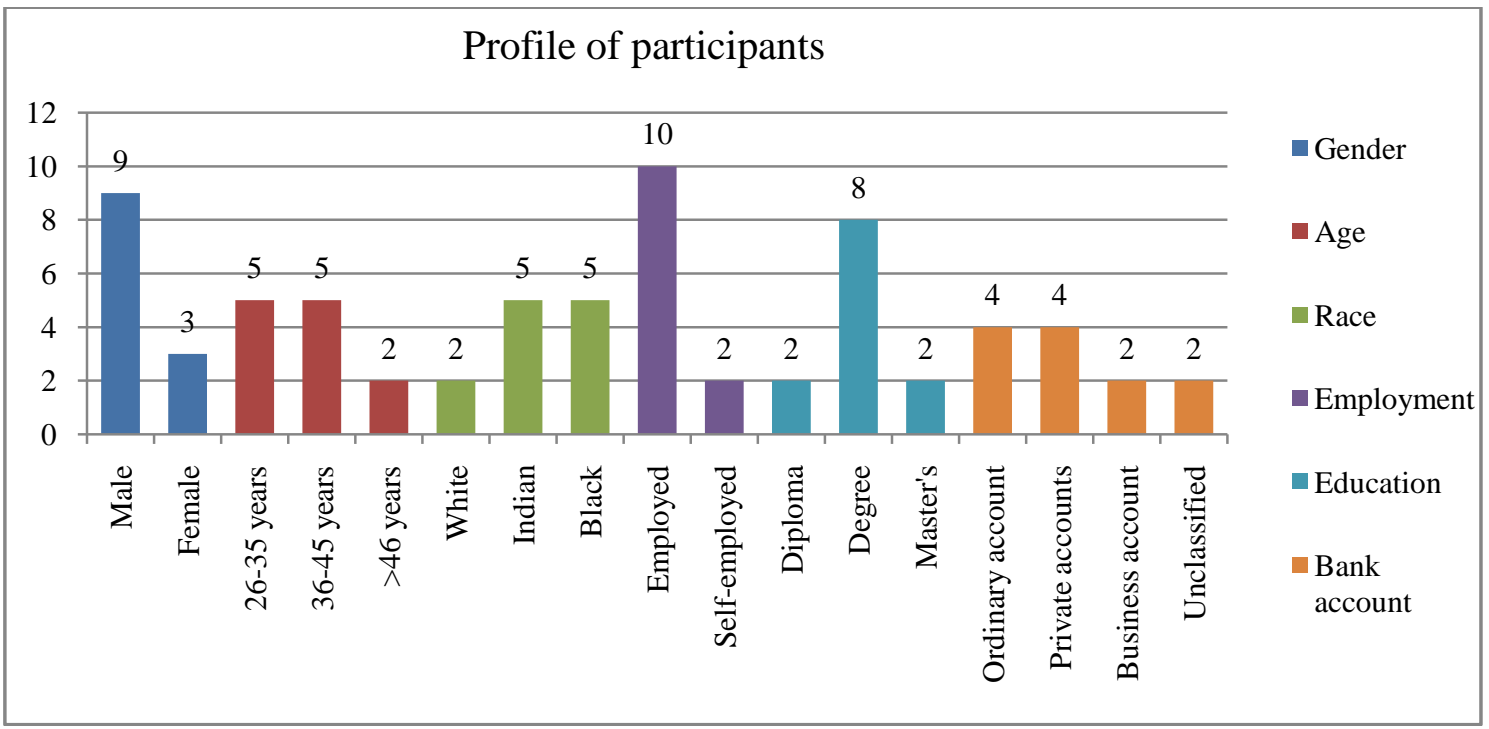

\section{Figure 1: Profile of participants}

\subsection{Presentation of the themes}

The majority of the themes and sub-themes were transcribed and interpreted from the interview guide and the occurrence of each team is displayed in Figure 2 below.

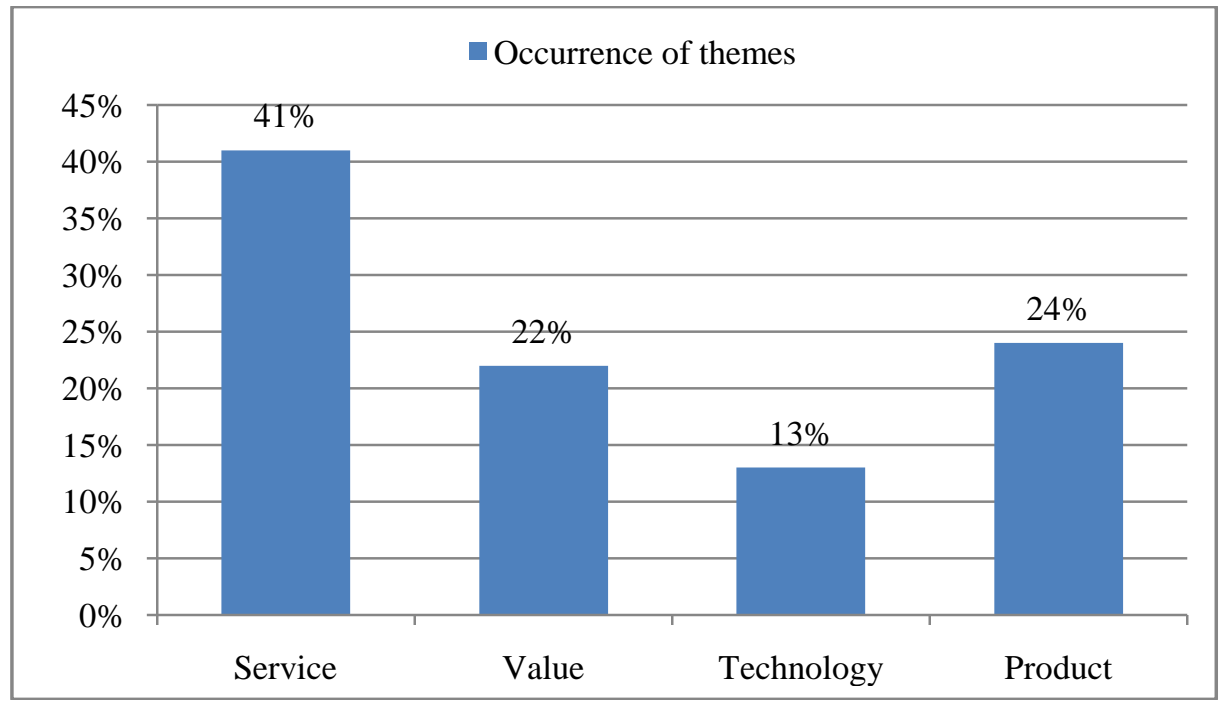

Figure 2: Occurrences of themes 


\subsection{Discussion of themes}

\section{Theme 1: Service}

The results indicated that the theme "Service" produced the highest number $(41 \%)$ of utterances and was mentioned almost two times more than the fourth theme "Product". It is evident that the service which a bank offers will determine whether the customer remains with that particular bank or not. Hence, customer service was found to be the most important factor for a bank to retain its customers. The bank's service was described as, but not limited to, the following: slow, poor communication, impersonal treatment, not understanding customer needs, and staff inability to execute an instruction. The results suggest that participants seek recognition and acceptance from their bank - a sense of belonging. Participants feel that there is a significant difference between banks servicing an existing customer and servicing a new customer.

\section{Theme 2: Value}

This theme had the second fewest utterances (22\%). Participants have an impression that bank costs are exorbitant, that the bank costs structures are not easy to understand and they do not see the value of the service. The results suggest that bank costs were never the primary reason for a participant switching banks. A closer examination of the data discovered close relationships between the theme "value" and the theme "service". Customers felt that they were not getting true value from the service that they paid for.

\section{Theme 3: Technology}

This theme produced the fewest utterances (13\%). Participants' understanding was that technology saves time and money, meaning that one does not have to stand in a queue for certain banking requirements (for example transferring money or paying accounts). Participants mentioned that mobile banking was one of the many technological advances that banks have introduced as an offering and that is helping to improve their quality of life. Customers are progressively becoming "tech-savvy", and the participants mentioned that the benefits are speed, convenience and cost savings.

\section{Theme 4: Product}

The theme "product" produced the second highest number of utterances (24\%). Participants felt that the quality of products offered in the banking sector lacked flexibility and did not meet their specific needs. A relationship was discovered between the themes "product" and "technology" that suggested that participants perceive a bank's product as being closely linked to technology or dependent on technology. Participants reacted positively towards being rewarded by the bank for using a particular product.

\subsection{Discussion of participant's responses}

\section{Ranking of themes}

Participants reasons for switching banks were translated into themes, sub-themes and theme statements, which were then quantified and categorised to present the themes on a continuum scale. Customer rankings were found to be compatible with the most important reasons why they changed banks. The understanding is that customers have comparable experiences and expectations when it comes to banking. Furthermore, although the participants had various types of bank accounts, their experiences were related.

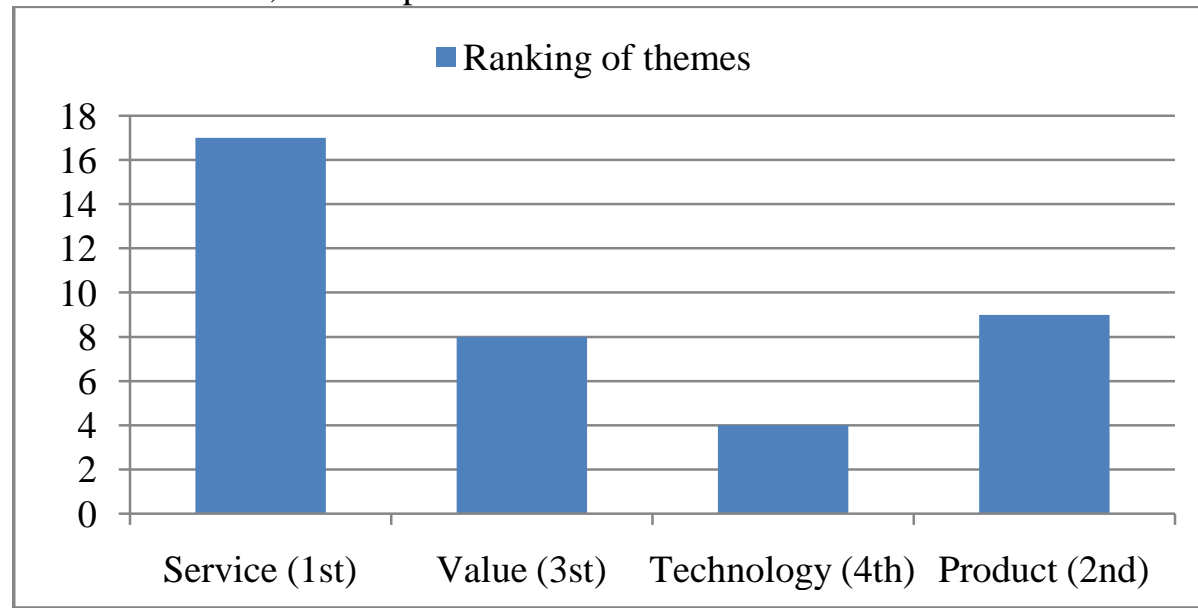

Figure 3: Ranking of themes 


\section{Theme 1: Service}

The results indicated that the participants wanted a "personal touch" (an experience that would make them feel special). They looked for a "partnership relationship" with their bank, where lines of communication would be clear, concise and transparent. The analysis also revealed that there was a close relationship between the themes "value" and "service". Essentially, customers felt that they were not getting true value from the service for which they had paid.

Sub-theme 1.1: Service quality

Although participants were holders of various bank accounts, it was found that customers look at banking as a partnership between the bank and the customer.

Sub-theme 1.2: Service availability

Participants indicated that quick, easily available facilities that are simple to use, and short turnaround times are typical characteristics of service availability.

\section{Theme 2: Value}

Participants felt that bank fees were difficult to understand and not transparent enough to the customer. They felt that they were not getting true value from the service for which they had paid.

\section{Sub-theme 2.1:Value proposition}

Participants indicated that they were not receiving value for the amount of bank fees that they were being charged. Sub-Theme 2.2: Fees

Participants felt that banks were over-charging their customers and do not see the value of the fees being charged in comparison to the quality of the services being received.

\section{Theme 3: Technology}

Participants felt that "technology" was an important theme, as they felt that they were "getting something out" when they used their bank account.

\section{Sub-theme 3.1:Progression}

In response to the process of keeping up with the advancements in banking, the participants' perspective concerned how well banks made use of technology to innovate and delight the customer. Participants were aware that by making use of mobile banking facilities, they will save on bank fees.

\section{Theme 4: Product}

Advances in technology and mobile banking give customers the freedom to bank anywhere and anytime. Banks are continuously developing products that appeal to customer needs. Analysis of participants' transcripts demonstrated a relationship between the product theme and the technology theme, suggesting that customers perceive bank products to be closely linked to technology.

\section{Sub-theme 4.1:Product quality}

Product quality is a group of features and characteristics of a saleable good, which determinesits desirability and which can be controlled by a manufacturer to meet certain basic requirements (OBD, 2013).

\section{Sub-theme 4.1.1:Flexibility on products}

Flexibility on products is the ability of a utility to adapt to its customer's needs and requirements. Banks are delivering on the increasing needs of their customers by introducing reward programs, online banking, free data bundles and free mobile devices to make banking more appealing and exciting. The challenge that banks are faced with is finding a balance between customer needs from a product perspective and providing offerings flexible enough to meet the customer needs with very little or no increase in cost to the bank.

Sub-theme 4.2: Product range

Product range refers to the collection of products or services that a bank provides to its customers. The participants indicated a desire for a wide assortment of products with the ability to integrate with each other.

Sub-theme 4.3: Integrated service offering 
Integrated service offerings can be described as the inter-link between one product and another. If a customer has multiple products with a particular bank, then that customer would like to have a single platform to view and transact with these products. The participants showed an interest in banks, which had integrated products.

\section{Conclusions}

The motivation for the study emanated from the literature survey, which highlighted the impact of the 2008 global financial economic crisis, combined with pressure that banks are facing to sustain income growth in the face of fading customer confidence. Banks responded to these economic challenges by aggressively targeting those customers leaving rival banks to grow their business. This study followed the interpretive research philosophy using a qualitative research methodology to understand customer's feelings and perspectives on switching banks. A theme codebook was developed based on the literature and participants' utterances.

The theoretical overview concerned studies relating to customer retention in the banking sector. The literature review indicated that among the most pressing issues facing the banking industry was customer retention, which negatively affects the improvement of revenue growth. It was found that it is more economical to retain existing customers than to attract new customers, and the majority of a company's business comes from current satisfied customers. This was also highlighted by Ahmad and Buttle (2009), who state that banks currently give more attention to the number of new customers they can obtain, whereas Erdis (2009) demonstrates that loyal customers generate more revenue over more years. Hence, banks face losing customers to rival banks, which translates into a decrease in revenue.

The primary objective of this study was to explore factors, which bank customers consider in their decision to leave their current bank for a competitor. Transcribed conversations with participants were thoroughly analysed to determine the factors which banking customers consider in their decision to leave their current bank for a competitor. Furthermore, these factors were linked to the available literature. It was found that banks' quality of service was criticised the most. Participants felt that banks were not providing a service of value to their customer. This primary objective was achieved in the study. As further research, it is recommended that a similar study be extended to other banks and service industries.

\section{References}

Aguinis, H, Gottfredson, RK. \& Joo, H. (2012). Using performance management to win the talent war. Business Horizons, 55(6), 609-616

Ahmad, R. \& Buttle, F. (2009). Customer retention management: A reflection of theory and practice. Marketing Intelligence \& Planning, 20(3), 149-161.

Alvarez, LS., Casielles, RV. \& Martin, AD. (2011). Analysis of the role of complaint management in the context of relationship marketing. Journal of Marketing Management, 27, 143-164.

Banking Association of South Africa. (2012). South African banking sector overview. http://www.banking.org.za/index.php/our-industry/2012-south-african-banking-sector-overview/. Date accessed: October 2013.

Baumann, C., Burton, S. \& Elliott, G. (2008). Determinants of customer loyalty and share of wallet in retail banking. Journal of Financial Services Marketing, 9(3), 75-238.

Bloemer, J. \& Kasper, H. (2008). The complex relationship between customer satisfaction and brand loyalty. Journal of Economic Psychology, 16(2), 160-166.

Boulding, W., Kalra, A., Staelin, R. \& Zeithaml, V. (2009). A dynamic process model of service quality: From expectations to behavioral intentions. Journal of Marketing Research, 30(1), 18-74.

Braun, V. \& Clarke, V. (2006). Using thematic analysis in psychology. Qualitative Research in Psychology, 3(2), 4-8.

Brink, A. \& Berndt, A. (2008). Relationship marketing and customer relationship management and customer service. Landsdowne. Juta.

Cohen, D., Gan, CR., Au Yong, HH. \& Chong, E. (2007). Customer retention by banks in New Zealand. ProQuest. Banks and Bank Systems: 40-56.

Colgate, M. \& Lang, B. (2011). Switching barriers in customer markets: An investigation of the financial service industry. Journal of Customer Marketing, 18(4), 332-347.

Deloitte. (2013). The Deloitte 2013 banking industry outlook. Date accessed: 1 June 2014 (the article has since been removed from the Deloitte's website. 
Denzin, NK. \& Lincoln, Y. (2013). The landscape of qualitative research. (4th ed), Thousand Oaks, CA: Sage.

Du Plessis, L. (2010). Customer relationship management and its influence on customer loyalty at Liberty Life in South Africa. Unpublished MCom thesis. Johannesburg: University of Johannesburg.

Erdis, C. (2009). Investigating customer service in selected restaurants in the Tshwane area -An exploratory study. Published MCom dissertation, University of South Africa.

FFin24 staffer. (2015). Rude staffers top reason why people switch banks. News24. www.fin24.com. Accessed $18 / 08 / 2015$.

Griffin, J. \& Lowenstein, M. (2001). Customer winback: How to recapture lost customers and keep them loyal. San Francisco: Jossey-Bass.

Guest, G., Bunce, A. \& Johnson, L. (2006). How many interviews are enough? An experiment with data saturation and variability. Field Methods, 18(1), 59-82.

Henning E., Van Rensburg W. \& Smit B. (2004). Finding your way in qualitative research. Pretoria: Van Schaik.

Hennig-Thurau, T. (2004). Customer orientation of service employees - Its impact on customer satisfaction, commitment and retention. International Journal of Service Industry Management, 15(5), 460-478.

Hoffman, K.D. \& Bateson, J.E.G. (2006). Services marketing: Concepts, strategies and cases. (3rd ed), Mason, $\mathrm{OH}$ : Thompson South-Western.

Howcroft, JB. (2007). Customer satisfaction in retail banking. The Service Industries Journal, 11(1), 11-17.

Johnston, R. \& Kong, X. (20110. The customer experience: A road-map for improvement. Managing Service Quality, 21(1), 5-24.

Lassignardie, J. \& Desmarès, P. (2012). World retail banking report 2012. www.it.capgemini.com/chi.../worldretail-banking-report-2012. Date accessed: 20 October 2012.

Libai, B., Narayandas, D. \& Humby, C. (2009). Toward an individual customer profitability model: A segmentbased approach. Journal of Service Research, 5(1), 69-76.

Marshall, C. \& Rossman, GB. (2011). Designing qualitative research. 5th edition. Thousand Oaks, CA: Sage.

Matanga, A. (2008). An investigation into the impact of customer service quality on customer satisfaction with particular reference to the carbonated soft drink industry in South Africa. Published MBL dissertation, University of South Africa.

Maurer, C. (2011). The measurement of information flow efficiency in supply chain management. DCom thesis, University of South Africa.

Mouton, J. (2001). How to succeed in your master's and doctoral studies: A South African guide and resource book. Pretoria: Van Schaik.

Online Business Dictionary. (2013). www.businessdictionary.com/. Date accessed: 15 December 2013.

PricewaterhouseCoopers. (2011). Unlocking opportunities: Strategic and emerging issues in South African banking 2011. https://www.pwc.co.za/en/assets/pdf/sa-banking-2011-v2.pdf. Date accessed: August 2014

PricewaterhouseCoopers. (2013). Shaping the bank of the future South African banking survey 2013. http://www.pwc.co.za/en_ZA/za/assets/pdf/south-african-banking-survey-2013.pdf. Date accessed: August 2014

Reichheld, F. (2009). The truth of customer retention. Journal of Retail Banking, 13(4), 21-104.

Rootman, C., Tait, M. \& Sharp, G. (2011). Relationship marketing and customer retention lessons for South African banks. Southern African Business Review, 15, 184-202.

Soranno, V. (2009). Customer profiles are key to loyalty. Discount Store News, 38(3), 14-55.

Verint ${ }^{\circledR}$. (2015). Poor Customer Service is Eroding Customer Loyalty to Retail Brands. Actionable Intelligence ${ }^{\circledR}$ solutions. www.verint.com

Yoshida, M. \& James, J. (2010). Customer satisfaction with game and service experiences: Antecedents and Conséquences. Journal of Sport Management, 24(3): 338-361. 